\title{
Journeying Beyond: Digital Storytelling with Rural Youth
}

\author{
Bea Staley \\ Charles Darwin University
}

This paper describes a digital storytelling project, completed with two classes of "non-college bound" Seniors at Shady Grove High School in the Midwestern United States. Using narrative inquiry as a methodological framework, student's stories were examined and considered as meaningful contributions to current knowledge about issues in rural education. Three broad themes revealed themselves in the student's work: 1. High school is viewed solely as a pipeline to college, 2. High school is not seen as "useful" or meaningful for students with career aspirations that do not require a four-year college degree, and 3. High school is mediated through the relationships formed there (teacher and peer). This project revealed the complex and complicated ways in which one group of rural students engaged with digital literacies to reflect on who they are, how they see themselves, and how they view their educational experiences connecting to their future selves.

Keywords: rural youth, adolescence, high school, narrative inquiry, digital storytelling

Rural schools often serve as social and cultural community centers that educate multiple generations of families; are sites of shared educational and historical experiences for community members; and maintain local identities and tradition (Bard, Gardener, Wieland, 2005; Morton \& Harmon, 2011; Schafft \& Jackson, 2010; Wake, 2012). In the 20112012 report "Why Rural Matters?” (Strange, Johnson, Showalter, \& Klein, 2012) the authors report 9,628,501 students - or 20.2\% of American students - living in rural school districts and being educated in rural public schools (Strange, et al., 2012). Despite these numbers, the body of research on this population remains relatively small (Coladarci, 2007) and the dearth of literature on the nuanced, complicated and storied lives of rural students and the educational challenges they face is remarkable. Further, these same schools are expected to conform to a national education agenda that is often designed without taking the roles and the resources of rural schools into full consideration (Arnold, 2005), because the national agenda effectively "removes local decision making” (Foster, 2004, p. 181) such that policy and curricular mandates may present a differing set of values to those of the community expected to enact them (Schafft \& Jackson, 2010).

What is documented however, is the outmigration of young people from rural communities (Carr \& Kefalas, 2010) supported in part by the current philosophy of today's education system, which is heavily influenced by neoliberal leanings and an emphasis on globalization (Schafft, Killeen, \& Morrissey, 2010). Rural schools are expected to operate under the premise of modernity, with a push to educate youth as mobile, adaptable, and "flexibly responsive to changing labor market conditions" (Schafft \& Jackson, 2010, p. 2) while ultimately elevating rural people themselves (Corbett, 2013b). It is a system that promotes the production of "effective workers who can compete in the global economy” (Foster, 2004, p. 180) and serves to encourage rural youth to leave their communities and imagine themselves in more urbane lives (Brooke, 2012; Corbett, 2006; Howley \& Howley, 2010). That is, curriculum is designed and delivered under the assumption that living in urban/suburban spaces is and should be the desired destination even for rural youth.

Despite the numbers of rural students, and the issues listed above, in mainstream discourse, "rural" is often unseen, trivialized, and considered irrelevant (Donehower, Hogg, \& Schell, 2012; Theobold, 2012), positioned as the "antithesis of modernity" (Corbett, 2013b, p. 1). Complex social issues may be simplified by casting them as character traits (Corbett, 2013b), rendering the diverse and varied lives of rural people — and indeed their communities - unacknowledged (Donehower, et al., 2012). This digital storytelling project was part of a larger doctoral thesis designed to emphasize the voices of rural students by highlighting their educational narratives and desires, on the one hand, and by considering the context of rural education and 
the ongoing marginalization of rural youth, on the other hand.

Given that the political focus of public schooling is currently on standards and assessment with teachers facing increasing pressure to teach the test (Ayers, Ladson-Billings, Michie, \& Dee, 2008), the message that is communicated to students and educators across the United States is that graduates must know a finite, predefined set of facts and applications regardless of the varied contexts and experiences they already have from non-school environments. Problematically, this focus at the expense of students' funds of knowledge (Moll, Amanti, Neff, \& Gonzalez, 1992) and privileges certain information that has been determined by educational “experts” and policymakers as valuable and necessary (Foster, 2004). Parents and educators in rural communities interested in preparing students for life in their community context often come into conflict with school systems, and are cast as "backward and not knowledgeable enough to know what was best for education” (Bard, et al., 2005, p.4). Though in reality these parents and educators are not often invited into conversations about what is taught and how students might actually 'use' or apply said knowledge in their day-to-day lives.

\section{Research Questions}

There is an underlying assumption to this work, that young people are creators and storytellers (they are, potentially, critical inquirers), and that their stories of education can serve as meaningful contributions to current knowledge about issues in rural education such as the relevance of standardized curriculum, college access and readiness, and educational inequity. In this research, students were assigned a digital storytelling project as a part of a class, which was mandatory for high school graduation. Their story projects were guided by prompts, all related to student's educational experiences (see Appendix A). The research questions underpinning this study were: How do rural, non-college bound, students - at Shady Grove High School - interrogate their educational experiences through digital storytelling? As these students consider their experiences, how do they perceive facets of the education system to support or hinder their future aspirations?

Theoretically, I understand and come to critique student's stories through the framework of critical multiculturalism (May \& Sleeter, 2010), and methodologically, I gathered, and analyzed their perceptions by turning to narrative inquiry (Clandinin \& Connelly, 2000). This orientation allowed me to investigate the ways in which students are storying and storied beings who make, interpret, and reinterpret meaning through the stories they tell and retell (Clough, 2002; Maynes, Pierce, \& Laslett, 2008). The digital stories are contextually and historically situated stories of education as told by the youth who experienced them. They are products of a specific time, place, and perspective and shed light on what it means to be a high school student graduating from a particular rural high school in the United States Midwest in the year 2013.

\section{Digital Storytelling}

Digital storytelling is a form of storytelling that simultaneously leverages voice, still images, and printed text to tell a short story (Lambert, 2009; Ohler, 2010; Robin, 2008). Digital stories are typically first person narratives spoken over a series of accompanying pictures, selected to add depth and meaning to the auditory presentation. Three to five minutes is the recommended duration for digital stories, which means they rely on succinct, economical storyline (Lambert, 2009).

In general, stories serve as accounts and, in turn, "accounts make actions at least recognizable and understandable to third parties, if not necessarily legitimate and acceptable” (Frank, 2010, p. 30). Thus, through the act of storytelling, rich opportunities emerge for students to (re)consider and (re)constitute the narratives by which they live (Bell, 2010; Bruner, 2002; Frank, 2010; Holstein \& Gubrium, 2000). Further, stories give individuals the power to see possibilities by telling variations of a story about themselves and their lives, opening the possibility to live by these alternative narratives (Bruner, 2002; Frank, 2010). In other words, stories, digital or otherwise, "offer alternative worlds that put the actual one in a new light” (Bruner, 2002, p. 10).

In many schools, certain voices are privileged as other voices are silent or silenced (Fine \& Weiss, 2003; Kozol, 1991), and this distinction replicates systemic power hierarchies in that certain students dominate conversations related to school experiences (e.g. bullying, see Wiseman, 2009). Digital stories may serve as a medium to "give students a voice to articulate heterogeneous positions in interdisciplinary and transdisciplinary dimensions of cultural critique" (Opperman 2008, p. 185) and encourage students to 
become producers of their own narratives (TaubPervizpour, 2009) instead of consumers of the stories others create about them. This was one salient reason for choosing to utilize digital stories in the rural school context.

Lowenthal (2009) argues that there are multiple additional educational benefits of digital storytelling, including: increased student engagement, access to a broader more authentic (online) audience, the amplification of individual voices, the leveraging of multiple literacies, and the harnessing of student emotion (see also Opperman, 2008; Selfe \& Selfe, 2008). Digital storytelling can also be used as a tool to provide students with opportunities to identify sociopolitical and community issues as they learn to communicate their concerns, fears, and hopes by producing potentially powerful stories that can impact self and others (see Hull, 2003; Lambert, 2009; Taub-Pervizpour, 2009).

Further, through this type of multimodal engagement with literacy projects, it is possible to work with students to explore justice and injustice as witnessed in their communities (e.g. Kinloch, 2010), and support their development of the critical skills necessary to become directors - rather than simply actors - in their journeys as students, and citizens. Thus avoiding the role of the chorus in a plot that serves to maintain the current social order and capitalist leanings of the contemporary education system (May \& Sleeter, 2010; McLaren, 2005). Hull (2003) notes that one of the most significant aspects of using digital storytelling is the "distinctive contrasts to the primarily alphabetic texts and the forms of textual reasoning that predominate in schools and universities” (p.230). Digital technologies offer the possibility for young people to use programs (e.g. iMovie, Windows Movie Maker, YouTube, Flickr) they are often already fluent in and serve as potentially powerful pedagogical tools in the classroom (Bailey, 2011; Robin, 2008; Selfe \& Selfe, 2008).

Digital storytelling was the selected project for this study because it provided students with a substantial opportunity to reflect on their past experiences and their future aspirations as they considered their lives within and beyond their high school. It also allowed students to engage with

\footnotetext{
13 Definition from

http://nces.ed.gov/surveys/ruraled/definitions.asp retrieved 4/6/16. The rural-fringe designation means that the school is located in a
}

technology, a current curricular emphasis at Shady Grove High School where the study took place, and part of a skill set required for many jobs (and university). Finally, digital storytelling was a tool to help teachers and administrators understand students' experiences (Wake, 2012) as they work to provide better academic programming to meet student needs.

\section{Method: Creating Digital Stories Researcher Positionality}

This study took place in a predominately white, mid-sized, public, educational institution, identified as Shady Grove High School for the purpose of this research. Shady Grove High School has a rural-fringe designation ${ }^{13}$, as assigned by the US Census Bureau. As a researcher I was connected with the principal and the school via a colleague who had taught previously at the school.

Though I was in the classroom with the teacher during the semester this research took place, and though I sometimes led the class (e.g. introducing the project, showing students how to do Creative Commons searches etc.) and supported the students with their project, I did not grade student work, or provide any classroom input around behavior. My role could be best described as a participant-observer. As an Australian American, with accented speech, I was an outsider at both the onset and conclusion of the study.

\section{Participants}

The students who participated in the digital storytelling project did so as a part of a senior year class called Journey Beyond Shady Grove, which was the school's alternative to the course, Journey to College. Students were required to take one or the other to graduate. Though students enrolled in the Journey Beyond course were viewed as 'non college bound,' it was notable that many of them reported career plans that required post high school education. Others had firm plans to go onto two-year college programs, making the catchall phrase 'non college bound' inaccurate for many of the students, particularly those who had applied for and been accepted into technical schools.

Across the two class periods of the Journey Beyond course there were 30 males and 19 females

"territory that is less than or equal to 5 miles from an urbanized area, or a rural territory that is less than or equal to 2.5 miles from an urban cluster.” 
whose ages ranged between seventeen and nineteen years old. Twenty-five of these students consented to share their work for this research, and their narratives were included in the thematic analysis.

\section{The Digital Storytelling Process}

While digital storytelling provides students an opportunity to produce something tangible that is available for future sharing, it also required students to have sustained engagement with their projects. Despite the brevity of the product it required careful scripting in order to produce a cohesive, concise, and linear story (Lambert, 2009). Students then recorded themselves reading the text, before adding that audio recording to the storyboard. Next, the process required focused manipulation of images, as well as the layering of soundtrack to convey meaning (Lambert, 2009). Thus, digital story telling products require considerably more class time -and technological support from teachers - than other, more traditional assignments (e.g., writing a paper; giving a speech).

Access to technology and proficiency using programs and software is essential for digital storytelling. One way this can be ameliorated is by having students work in small groups (see Wake, 2012). However, a group narrative, and the negotiation -of time, talent, work- required to produce a group story is a completely different type of final product than the one presented here, or indeed developed by Lambert (2009) and the Center for Digital Storytelling ${ }^{14}$.

Because Shady Grove High School had implemented one-on-one computing the year of this project, all students already possessed their own school laptops for use throughout the school day. Not having to share computers for assignments meant that digital storytelling became a viable project and the necessary software (e.g. Windows Movie maker) was loaded onto their laptops during class time.

Though the Digital Storytelling center (Lambert, 2009) provides a framework for conducting digital storytelling workshops, high school class timings (41-minute daily sessions) prohibited a replication of their format. Instead, designated weeks were set for the students to complete project tasks (see Table 1). Students worked on the project daily during the six weeks of class time. After the six weeks concluded, the class moved onto a new assignment and students had to finish their stories on their own time. The timeline was developed with the classroom teacher based on her experiences with the student group, and was adapted as needed throughout.

Table 1

Digital Storytelling Timeline

\begin{tabular}{ll}
\hline Date & Activity \\
\hline Week 1 & $\begin{array}{l}\text { Introduce the project including the prompts for eliciting student stories (See Appendix 1). } \\
\text { Movie Maker software downloaded onto student netbooks. Students are asked to } \\
\text { brainstorm, or outline their story. }\end{array}$ \\
\hline Week 2 & Students produce a typed 2-page double spaced narrative for their digital story in Word. \\
\hline Week 3 & $\begin{array}{l}\text { Digital Story examples are viewed. Class discussions initiated about choosing images, the } \\
\text { power of images and using Creative Commons }{ }^{15} \text { to find pictures. Students began to select } \\
\text { images, students who are finished with their script began to record their story. }\end{array}$ \\
\hline Week 4 & $\begin{array}{l}\text { Movie Maker tutorial: a 'how to’ of digital story creation. Class discussions about using } \\
\text { text/picture effects, picture transitions and selecting music. Jamendo, a site that has free } \\
\text { music available for sharing introduced. }\end{array}$ \\
\hline Week 5 & $\begin{array}{l}\text { Students work on assembling their stories in Movie Maker (e.g. synchronizing audio, } \\
\text { pictures and effects). }\end{array}$ \\
\hline Week 6 & Wrap up, students begin to work on their digital story reflections/meta-notes. \\
\hline
\end{tabular}

In most class sessions, we had a ratio of two reasonably tech savvy- adults to 25 students (per class period) during the six-week project. Even so,

\footnotetext{
${ }^{14}$ Educators considering digital storytelling with students might best guide a project if they have already had the experience of creating their own digital story.
}

projects still evaporated from netbooks, there were technical glitches and things went awry. Rather than detail the storytelling process which I have written

\footnotetext{
${ }^{15} \mathrm{http}: / /$ search.creativecommons.org
} 
about elsewhere (Staley \& Prince, in submission), I will share the broad results of this work, and connect these to the ways digital storytelling provided an avenue for rural youth to share about their school experiences, and gave school administrators an insight into the lives of their students who had been described as "unmotivated, low functioning sometimes for reasons they can't control or we don't even know about" and with "major behavior issues" (field notes, September 4, 2012).

\section{The Field Note Process}

Field notes were taken throughout the project and considered data (Clandinin \& Connelly, 2000; Connelly \& Clandinin, 1990). I used an Apple iPad to make classroom recordings of conversations, as well as document quotes and observations as I worked with the students during class time. After class, I met with the classroom teacher, and then often sat in my car and dictated thoughts and observations, which were later transcribed. Though the student's digital story scripts, transcripts of narrative interviews and other written classwork were used as the primary data source, my observations and field notes provided a supportive context in interpreting the student's words.

\section{Coding and analysis}

The data was printed, and coded by hand. Student's narratives were analyzed for themes and patterns that emerged (Pinnegar \& Hamilton, 2011) across their digital stories, classroom conversations, interviews and coursework. Initially data was sorted by student pseudonym, and as their data was transcribed, I kept a separate word document noting ideas, questions, and key words. I recorded the major themes in each of the pieces of student's work (three assignments in particular) as well as their interviews. I then reviewed and re-viewed the data, shifting the data into larger themes that arose across narratives, continuing to sift through the information until I was satisfied with the refinement of the categories.

\section{Member checks}

Throughout the study I asked students about any questions that arose. These conversations were captured in my field notes. Students had graduated and were not available for final member checks by the time my analysis was complete. The research however was shared with the principal and classroom teacher and we met to discuss their thoughts around my understandings and interpretations of the student's storytelling. Both the teacher and the principal had viewed the complete set of digital stories prior to reading this work.

\section{Findings}

This paper seeks to demonstrate the way one rural-fringe, public, high school encouraged the meaningful use of digital storytelling to start an important conversation about rural education from the perspective of their 'non college bound' student population. Although the students generated a myriad of individual stories, in this paper they were viewed using what might best be described as a thematic analysis (Pinnegar \& Hamilton, 2011), looking at the themes and patterns that emerged across students' work. I present a synopsis of the thematic findings that other researchers and educators may find informative when considering pedagogical and curricular decision making with rural youth.

\section{Students View High School as a Pipeline to College}

Many of the students in this study, reported critically - that the primary purpose for Shady Grove administrators was to get their students into college. As 'non college bound' students, they thus felt that high school served little purpose to the trajectory of their lives, and was merely "babysitting" (meeting with principal, field notes). Claire's digital story text in particular, serves as an exemplar for this theme. For example, in Claire's story she stated, "College. The “ideal” destination for Shady Grove students after high school. That's where they want us all to go.”

This is reported as a negative stance with students sharing high school experiences about the times when they had been pushed toward a college pathway they had little interest in pursuing. Claire believed this was an administrative mindset that disregarded students who did not follow the school's prescribed pathway. As a result, this cohort of students did not see their interests as central to any of the decisions being made by the school-based personnel. Claire wrote:

..when I was sitting in the guidance office my sophomore year, they were trying to persuade me onto "the path," the path of a 4 year college. When I told her about my plan to go to school to be a licensed cosmetologist, she didn't exactly approve. So there it was. The only 
option they wanted me to have. Her words were, "that's fine ' $n$ ' all if that's what you think you want to do.. but with your grades and intelligence you need to have a college back up plan.” Does that mean college bound students are supposed to have a technical back-up plan if it doesn't work out for them? Nope, of course not.

Given that, $48 \%$ of Shady Grove's seniors do not go on to four-year colleges, (7\% of these students join the military, and administration is not sure what the remaining $41 \%$ of the students do) postgraduation, the singular college bound focus does not meet the needs of a substantial portion of the student population. Yet, despite the non-college stance of the rural students in this research, in one way or another, they presented evidence that pointed to their desires to obtain a job, earn a good salary, and acquire a home. Claire noted:

I'm a very realistic person, so I have the worries and fears of not succeeding and not making a good living for myself, especially in an economy like this. But multiple people in my family are in the career that I want to be in and are very successful, like my dad for example. One could argue that the best way to prepare students to obtain these stated desires (especially during these times in which jobs are becoming increasingly scarce in rural areas) would be to ensure that they attain a college degree. But for those students who have already identified future careers in cosmetology, welding, tattoo artistry, or the service industry, students would like their high school education to contribute in meaningful ways to their career choices.

\section{Students Want High School to be Meaningful and Engaging}

The relevance of the high school curriculum was a frequent topic in this collection of digital stories. Student's explicitly noted that they wanted to high school to be meaningful and engaging, rather than a “waste of my time.” Ben's digital story was an exemplar of this category. He declared:

I think that school is worthless. I go to school and am bored out of my mind all day long. I sit there and learn nothing about what I am wanting to do in life. If I went to school and felt like I learned something that I would really use I would love coming and never complain.
Given the view that many students believe high school is a merely a college feeder that they feel a disconnect between the curriculum and their lives in hardly surprising. Carl stated the issue emphatically and comically- in his digital story when he said, "why would I ever ever ever need to find out what the square root of 257 is. I don't care what the square root is. I know what the square root of Algebra is. It's boring." Carl went on to give many other examples of material he believed he did not need to know (e.g. how many protons are in Helium?), but like Ben, his central point is that schools could make an attempt to be relevant for the lives of the students who inhabit the classrooms.

In the same way various student's articulated the desire for 'useful' curricular content, students requested classes that included active involvement in the learning material. Ben wrote: "One class like that is Ag. I work in that class, we track animals, look at the populations control, pond control and population, tree growth and tree population.... This is a class is stuff I actually use.”

Tim, whose digital story was about an out of school experience rebuilding a truck with his father, wrote that the experience taught him a lot "because it was all hands on. I'm not sure how you would make it [school] completely hands on but if it were more, then at least it would be a lot easier to learn for me.” His central point was that he learned when he had the opportunity to participate in the learning in a meaningful way. A large number of students similarly talked about their preference for "hands-on learning," indicating a rudimentary awareness of pedagogy and how teaching and learning might take place in the classroom if students were consulted.

Like Claire, Ben was concerned about the economics of his choices. He reported, "so when I get out of high school, I want to work outside all the time. And I think you can make a good living and support a family doing that. Especially if you run your business well.” Ben is a student that is better known for the trouble he causes, and his athletic abilities than his academic prowess. However, his story and his request for relevant curricula is apt and pointed. He continues:

I think I should have more classes that are relevant for what I want to do in life...Half of the kids in the school hate sitting here all day bored, doing nothing, we want to be doing stuff that we are actually going to be doing with our lives.... The teachers and administration should 
be asking the students what is it you are wanting to do, why they are choosing this and how should we form classes around these preferences.

\section{High School Experiences are Mediated Through Relationships}

In the third category of stories, high school students talked about relationships. In various ways, students made it apparent that teaching is not enough; they also want to be seen, known, and understood by educators. Students reported that they learned because of the relationships they had with teachers and other school based personnel who supported them. Further, the digital stories revealed school is lived in these connections and disconnections with teachers and friends, and is experienced in moments rather than years.

There were several digital stories about bullying and ongoing activities that shaped student's participation in school. Their narratives suggested that a good or bad moment can ricochet through a student's day/week/month/year. What adults might consider small incidences, such as a humiliation, a fight in the corridor, being told off, or receiving praise can feel like larger moments for students at the school.

Laura's digital story was an exemplar for this theme. Laura wrote about her experiences with bullying, a story which started "I've been bullied since I was a freshman... so I really didn't look forward to the rest of high school. All the girls kept saying when they see me in the hallway they're going to beat me up." She continues on to say:

I would tell the teachers and they didn't do anything about it. I would leave class early so I didn't have to see the girls in the hallway.... I told one of the teachers here and she just said not to listen to it, but it's really hard not to listen to it when you are sitting in class... and you don't want to cry but you have tears coming out of your eyes because you are so scared.

Though students reported positive and negative moments during their high school careers, it was clear that both large and small hostilities, which educators may be tempted to ignore, mark students' lives, particularly given the technology students now have at their disposal which allows for the swift capturing and sharing of discomfiture (Wiseman, 2009). In Laura's story she stated, “I think teacher’s need to get more involved, not try and stay out of the trouble.. well you don't want to get into it for the drama but you need to.. because you're the adult.” Her point was consistently corroborated, as other stories reported the ways in which incidents are overlooked in hallways and classrooms. The student stories highlighted their belief that adults at the school too easily neglect the moments of connections with students. These students indicated that educators treat these moments (both negative and positive) as irrelevant to student's educational experiences. Laura concluded:

I think people should realize that you NEED to get involved in the student's life. Its important for them to feel comfortable at school and are able to learn...I don't appreciate the teachers who avoided getting involved when they heard every insulting, hurtful word... If someone is getting bullied I want to help. I want to be there for someone because nobody was there for me.

\section{Discussion}

\section{High School as a Link to Perceived Futures}

Young people learn best when they can connect academic knowledge to their lives in meaningful ways (Delpit, 2002; Lee, 2007; Kinloch, 2010).

When students utilize their literacy skills in meaningful ways (Gustavson, 2008; Kinloch, 2010) they are motivated to inquire into issues they see as personally and politically important. Participation in meaningful activities also increases the likelihood that they will continue to engage in similar activities in ways that strengthens their literacy skills, as well as increases the ease and fluency of their participation in these activities in schools and in the larger world.

From the findings above, I have attempted to illustrate some of the concerns rural students revealed about their education via their digital storytelling projects. From student's stories and discussions I conclude that opportunities for imagining varied futures, and implementing steps towards those futures are narrow, in part due to the strong emphasis placed on college at the school, and in part because some professional trajectories are less valued than others (e.g. working on a racing car team, or becoming a mechanic).

The larger context for both this work and the students' stories is the interplay between what students want and what the system wants for them, 
even if students themselves are unaware of the systematic tugging and larger decision making that determines the content of their curriculum. As Corbett (2013a) noted, mobility opportunities are not equal for all students, and it was apparent in this data that some of these students did not perceive that they had a choice to pursue higher education, because of/despite their lived situational realities. Carr and Keflas (2010) suggest that communities put additional resources into students who plan to stay in their communities (rather than leave for college) to ensure the survival of rural communities. This is an important point, as it suggests a need for school administration to recognize and cultivate student's skills in ways which rural schools better account for the futures of their students.

Perhaps we could take a stance that school is not for everybody and we could foolishly aim to educate most of our students while paying little attention to the outliers who perform below expectation, and are typically our "Stayers" (Carr \& Kefalas, 2010) or our "non-college bound" youth. But as long as the law states that students are required to attend school for a set amount of years or until they reach a certain age, then we must continue to critique and query the education students are receiving. It is our responsibility to provide students with an education that is useful to who they are and who they seek to be, and one way to do this work is by relying on the usefulness and power of narrative work.

\section{High School as "Useful”}

Many students requested that school could be more useful to them, noting that in its current state, high school curricula was not explicitly applicable to their current aspirations. In many of the student's stories they revealed situations where the school had failed to gain an effective collaboration with in regards to their own learning process. In fact, by the time of this study (Fall semester, Senior year) the window of opportunity for meeting these students and genuinely reflecting on their aspirations in order to support their ongoing educational journey seemed to have closed. Arguably, earlier "active co-operation of the pupil in construction of the purposes" and the, "participation of the learner in the formation of purposes which direct his activities in the learning process" (Dewey, 1938, p. 67), could have resulted in different outcomes for these students.
Student's narratives point to the need for facets of the education system to better support and align with rural student's imagined futures. Harwood, McMahon, O'Shea, Bodkins-Andrews and Priestly’s (2015) work with Indigenous Australians asks educators to inspire disenfranchised students, in order to positively impact their engagement with schooling, rather than remediate them with a prescribed academic pathway.

While Hardré, Sullivan and Crowson’s (2009) work, revealed that when students perceive school to be "useful" then they are also much more likely to do the very thing school personnel want from them. This is significant because the perception of 'usefulness' is relatively malleable compared to other systemic factors of schooling: Teachers and administrations can be explicit about the practical value of learning material, linking learning to interests and aspirations of their students.

For some students, digital storytelling, was a forum for providing an outside-inside connection (Gustavson, 2008), by capitalizing on technological competencies for students who spent time gaming and engaged with music and images via the web. However, other students felt that the use of technology did not necessarily enhance their reactions to or interactions in school or preparation for the careers to which they aspired. For students who eschewed technology, the digital storytelling project at least gave them an opportunity to report on things they enjoyed (e.g. building a truck, their participation in sports).

\section{High School as a Place of Connection}

Young people, both inside and outside school, are constantly creating and recreating, defining and redefining their own identities (Holstein \& Gubrium, 2000; Raible \& Nieto, 2008) in regards to who they believe they are and seek to become. In relation to education, findings support prior research that suggests students do this in the context of the relationships they are in with teachers, administrators and their peers.

As Noddings (2005) wrote, “subject matter cannot carry itself. Relation, except in very rare cases, precedes any engagement with subject matter" (p. 36). Though school might not be a natural setting for some students to find a mentor, through students' digital storytelling, educators have the opportunity to get to know students and potentially form meaningful 
relationships with them as they also seek ways to meet their students' academic needs.

Amongst the findings in Irvin, Meece, Byun, Farmer, and Hutchins' (2011) study of 6,247 rural high school students is a positive relationship between students' subjective outcomes in their school experiences and their educational achievement and aspirations. Students who reported a greater sense of belonging and value in school also tended to do better academically. Creating positive moments has the potential to connect students with their teachers, schools and learning environment, which makes them more likely to succeed in that context. This is as Noddings (2005) writes, "students will do things for people they like and trust” (p. 36).

Contemporary scholarship is engaged in reframing the roles teenagers play in their communities, revealing them as active, thoughtful, and creative citizens (Corbett, 2013b; Gustavson, 2008; Vasudevan \& Hill, 2008; Kinloch, 2010; Morrell, 2008). Thus knowing what students want to learn and building curricular content from that place of knowing could enhance education in a myriad of ways. Importantly, it could engross students in a way that helps them see the value of education and the relevance of education in their lives. Considering rural youth as young people who utilize their talents to create and recreate meaning in their own lives despite (and perhaps because of) existing structural limitations, may help educators to enact culturally relevant and culturally sustaining pedagogical practices inside rural public schools.

\section{Implications For Educators}

This work suggests that teachers might include digital storytelling in their courses, because there is rich potential in story, and this digital storytelling project provided students with an opportunity to narrate their understandings of self and others in the world (Holstein \& Gubrium, 2000). In their stories, students revealed the complex and complicated ways in which they were reflecting on who they are, how they see themselves, and who they wished to become. Further, it was clear that students felt strongly about the purpose of schooling and how it related to their individual career trajectories, and for most of them, it didn't!

This project and the surrounding conversation allowed for this group of students to question the role of education in their lives as they reframed their schooling experiences and stories of self in positive ways. Schooling here served, not as an oft-reported "waste of time" (seen in field notes, digital story scripts), but as an opportunity for students to both share their perspectives and demonstrate their technological skills.

Perhaps there is an important pedagogical role in digital storytelling - the creation, production, and sharing of stories - as a tangible way to link what students do in high school with both the curriculum and their passions/future aspirations, or create “windows of aspiration” (Harwood, McMahon, O’Shea, Bodkin-Andres, \& Priestly, 2015). In this way, storytelling can be viewed as a space for challenging, critiquing and pushing students; as a way to help students develop their voices, not just become echoes. Their digital stories became what Morrell (2008) calls “living texts” (p. 170). The students were producing scripts that helped them create and recreate their identities of who they want to be as active participants in their lives and communities beyond higher education. Further, they helped student develop the skills they can harness (if they choose) as literate global citizens in technological communication environments (Selfe \& Selfe, 2008).

\section{Future Research and Limitations}

The stories elicited during this study were in many ways shaped by the digital storytelling prompts (Appendix A) provided, and the narratives were constrained by the classroom context in which they were gathered. However, this project was completed in two additional schools in the region (with 'ruraldistant' and 'city-large' designations) where similar prompts generated notably different narrative themes. Ongoing research using storytelling is warranted to further examine and respond to student's experiences in America’s public schools.

\section{Conclusions}

Ultimately, this study was designed to "help students make sense and impose meaning on their pursuit of academic tasks" (Lee, 2007, p. 27) with the view that "the main point of education (in the context of a lived life) is to enable a human being to become increasingly mindful with regard to his or her lived situation and its untapped possibilities" (Greene, 1995, p. 182). The student's stories do not lead to a nice, tidy summary. Rather, I continue to ask: Who are these students? Who will they become? How might rural schools better serve their needs by getting 
to know their needs? What is the role of story in this process of getting to know students? And, how might digital storytelling, move educators and students to a place of inquiry that is both critical and reflexive and that interrogates power relations in schools? These stories serve as ways into the lives of students; they are invitations for educators to connect with and listen to students in order for meaningful learning that must take place.

\section{Appendix A: Digital Storytelling Prompts}

The Shady Grove students were given the following digital story telling assignment prompt in the form of a worksheet:

As a Senior student we anticipate you are looking back on your high school years at the same time you are looking forward to your future. Based on your high school experiences choose from one of the options below:

Arnold, M. (2005). Rural education: A new perspective is needed at the U.S. Department of Education. Journal of Research in Rural Education, 20(3), 1-3.

Ayers, W., Ladson-Billings, G., Michie, G., \& Dee. R. (Ed.). (2008). City kids, city schools: More reports from the front row The New Press.

Bailey, B. (2011). "When I make a film, it's out of my head": Expressing emotion and healing through digital filmmaking in the classroom. Digital Culture \& Education, 3(2), 76-97.

Bard, Gardener, \& Weiland. (2005). Rural school consolidation report: National Rural Education Association.

Bell, L.A. (2010). Storytelling for social justice: Connecting narrative and the arts in antiracist teaching. New York, NY: Routledge.

Brooke, R. (2012). Voices of young citizens: Rural citizenship, schools, and public policy. In K. Donehower, Hogg, C., \& Schell, E. (Ed.), Reclaiming the rural: Essays on literacy, rhetoric, and pedagogy. Carbondale, IL: Southern Illinois University Press.

Bruner, J. (2002). Making stories: law, literature, life. Cambridge, MA: Harvard University Press.

Carr, P.J., \& Kefalas, M.J. (2010). Hollowing out the middle; The rural brain drain and what it means for America. Boston, MA: Beacon Press.
- Tell a story that illustrates how you think your high school education has/has not prepared you for your life beyond high school.

- Tell a story that illustrates why you think high school education is/is not important.

- Tell a story that illustrates your best or worst moment/event at school and the ways that this experience has shaped you.

- Tell a story that illustrates something high school administrators, teachers and policy makers need to know about you in order to make high school a better place for other students

- Tell a story that illustrates the ways school does/does not reflect your life outside of school and why this does/does not matter

\section{References}

Clandinin, D. J., \& Connelly, F.M. (2000). Narrative inquiry: Experience and story in qualitative research: Jossey-Bass.

Clough, P. (2002). Narratives and fictions in educational research: Open University Press.

Coladarci, T. (2007). Improving the yield of rural education research: An editor's swan song. Journal of Research in Rural Education, 22(3).

Connelly, F.M., \& Clandinin, D.J. (1990). Stories of experience and narrative inquiry. Educational Researchers, 19(5), 2-14.

Corbett, M. (2006). Educating the country out of the child and educating the child out of the country: An excursion in spectrology. The Alberta Journal of Educational Research, 52(4), 289301.

Corbett, M. (2013a). I'm going to make sure I'm ready before I leave: The complexity of educational and mobility decision-making in a Canadian coastal community. Journal of Rural Studies, 32, 275-282. doi:10.1016/j.jrurstud.2013.07.006

Corbett, M. (2013b). Improvisation as a curricular metaphor: Imagining education as a rural creative class. Journal of Research in Rural Education, 28(10), 1-11.

Delpit, L. (2002). No kinda sense. In L. Delpit, \& Dowdy, J.K. (Ed.), The skin that we speak: 
Thoughts on language and culture in the classroom. New York, NY: The New Press.

Dewey, J. (1938/1997). Experience and education. New York: Touchstone Books.

Donehower, K., Hogg, C., \& Schell, E. (2012). Reclaiming the rural: Essays on literacy, rhetoric and composition. Carbondale, IL: Southern Illinois University Press.

Fine, M., \& Weis, L. (2003). Silenced voices and extraordinary conversations: Re-imagining schools. New York, NY: Teachers College Press.

Foster, W.P. (2004). The decline of the local: A challenge to educational leadership.

Educational Administration Quarterly, 40(2), 176-191.

Frank, A. W. (2010). Letting stories breathe. Chicago, IL: The University of Chicago Press.

Greene, M. (1995). Releasing the imagination: Essays on education, the arts, and social change. San Francisco: Jossey-Bass.

Gustavson, L. (2008). Influencing pedagogy through creative practices of youth. In M. L. Hill, \& Vasudevan, L. (Ed.), Media, learning, and sites of possibility. New York, NY: Peter Lang.

Hardré, P., Sullivan, D., \& Crowson, H. (2009). Student characteristics and motivation in rural high schools. Journal of Research in Rural Education, 24(16).

Harwood, V., McMahon, S., O’Shea, S., BodkinAndrews, G., \& Priestly, A. (2015).

Recognising aspiration: the AIME program's effectiveness in inspiring Indigenous people's participation in schooling and opportunities for further education and employment. The Australian Educational Researcher, 42, 217236.

Holstein, J. A., \& Gubrium, J.F. (2000). The self we live by. New York, NY: Oxford University Press.

Howley, C., \& Howley, A. (2010). Poverty and school achievement in rural communities: A social-class interpretation. In K. Schafft, \& Jackson, A.J. (Ed.), Rural education for the twenty-first century: Identity, place and community in a globalizing world. University Park, PA: The Pennsylvania State University Press.
Hull, G. (2003). At last: Youth culture and digital media: New literacies for new times. Research in the Teaching of English, 38(2), 229-233.

Irvin, M.J., Meece, J., Byun, S., Farmer, T., \& Hutchins, B. (2011). Relationship of school context to rural youth's educational achievement and aspirations. Journal of Youth and Adolescence, 40, 1225-1242.

Kinloch, V. (2010). Harlem on Our Minds: Place, Race, and the Literacies of Urban Youth. NY: Teachers College Press.

Kozol, J. (1991). Savage inequalities: Children in America's schools. New York, NY: Random House, Inc.

Lambert, J. (2009). Digital storytelling: capturing lives, creating community (3rd ed.). Berkley, CA: Digital Diner Press.

Lee, C. D. (2007). Culture, Literacy, and Learning: Taking Bloom in the Midst of the Whirlwind New York, NY: Teachers College Press.

Lowenthal (2009). Digital storytelling in education: An emerging institutional technology? In J. Hartley, \& McWilliam, K. (Ed.), Story circle: Digital storytelling around the world. West Sussex, UK: Wiley-Blackwell.

May, S., \& Sleeter, C.E. (Ed.). (2010). Critical multiculturalism: Theory and praxis. New York, NY: Routledge.

Maynes, M. J., Pierce, J.L., \& Laslett, B. (2008). Telling stories: The use of personal narratives in the social sciences and history. Ithaca, NY: Cornell University Press.

McLaren, P. (2005). Capitalists and conquerors: A critical pedagogy against empire. Lanham, MD: Rowman \& Littlefield Publishers, Inc.

Moll, L.C., Amanti, C., Neff, D., \& Gonzalez, N. (1992). Funds of knowledge for teaching: Using a qualitative approach to connect homes and classrooms. Theory into practice, 31(2), 132141.

Morrell, E. (2008). Critical literacy and urban youth: Pedagogies of access, dissent, and liberation. New York: Routledge.

Morton, C., \& Harmon, H.L. (2011). Challenges and sustainability practices of frontier schools in Montana. Rural Educator, 33(1), 1-14.

Noddings, N. (2005). The challenge to care in schools: An alternative approach to education. New York, NY: Teachers College Press.

Ohler, J. B. (2010). Digital community, digital citizen. Thousand Oaks, CA: Corwin. 
Oppermann, M. (2008). Digital storytelling and American studies critical trajectories from the emotional to the epistemological. Arts \& Humanities in Higher Education, 7(2), 171187.

Pinnegar, S., \& Hamilton, M.L. (2011). Narrating the tensions of teacher educator researcher in moving story to research. Narrative Inquiries into Curriculum Making in Teacher Education Advances in Research on Teaching, 13, 43-68.

Raible, J., \& Nieto, S. (2008). Beyond categories: The complex identities of adolescents. In M. Sadowski (Ed.), Adolescents at school: Perspectives on youth, identity, and education. Cambridge, MA: Harvard Education Press.

Robin, B. (2008). Digital storytelling: A powerful technology tool for the 21st century classroom. Theory Into Practice, 47, 220-228.

Schafft, K.A., \& Jackson, A.Y. (2010). Rural education for the twenty-first century: Identity, place and community in a globalizing world. University Park, PA: The Pennsylvania State University Press.

Schafft, K., Killeen, K.M., \& Morrissey, J. (2010). The challenges of student transiency for rural schools and communities in the era of No Child Left Behind. In K. Schafft, \& Jackson, A.J. (Ed.), Rural education for the twenty-first century: Identity, place and community in a globalizing world. University Park, PA: The Pennsylvania State University Press.

Selfe, R.J., \& Selfe, C.L. (2008). "Convince me!" Valuing multimodal literacies and composing public service announcements. Theory into practice, 47, 83-92.

Strange, M., Johnson, J., Showalter, D., \& Klein, R. (2012). Why rural matters 2011-2012: The condition of rural education in the 50 states. A Report of the Rural School and Community Trust Policy Program. Retrieved from http://www.nwp.org/cs/public/download/nwp_fi le/15455/rural_school_communit

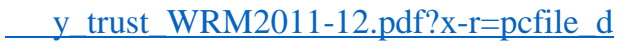

Taub-Pervizpour, L. (2009). Digital storytelling with youth: Whose agenda is it? In J. Hartley, \& McWilliam, K. (Ed.), Story circle: Digital storytelling around the world. West Sussex, UK: Wiley-Blackwell.

Theobold, P. (2012). Afterword. In K. Donehower, Hogg, C., \& Schell, E. (Ed.), Reclaiming the rural: Essays on literacy, rhetoric and composition. Carbondale, IL: Southern Illinois University Press.

Vasudevan, L. \& Hill, M.L. (2008). Moving beyond dichotomies of media engagement in education: An introduction. In M. L. Hill, \& Vasudevan, L. (Ed.), Media, learning, and sites of possibility. New York, NY: Peter Lang.

Wake, D. G. (2012). Exploring rural contexts with digital storytelling. Rural Educator, 33(3), 23-37.

Wiseman, R. (2009). Queenbees and wannabees: Helping your daughter survive cliques, gossip, boyfriends, and the new realities of girl world: Harmony.

\section{About the author:}

Dr. Bea Staley is a Lecturer in the School of Education at Charles Darwin University, in Australia. Bea has her Doctorate in Multicultural Equity Studies in Education from The Ohio State University. Bea has broad interests in language, literacies, and culturally relevant pedagogies, particularly for marginalised students. She can be reached at bea.staley@cdu.edu.au 